\title{
G6PD Deficiency and Favism in the Island of Rhodes (Greece) ${ }^{\star}$
}

\author{
CHRISTOS A. KATTAMISt, ATHANASIOS CHAIDAS, and STAVROS CHAIDAS \\ From the Department of Paediatrics, University of Athens, and the Haemolytic Anaemias Unit, \\ Choremis Research Laboratory, St. Sophie's Children's Hospital, Athens 608, Greece
}

Glucose-6-phosphate dehydrogenase (G6PD) deficiency is commonly encountered in Greece, but its distribution is uneven. Incidences ranging in the male population from $1 \%$ to more than $30 \%$ were described. As a rule high incidences were found in areas where malaria had been hyperendemic in the past (Zannos-Mariolea and Kattamis, 1961; Choremis, Zannos-Mariolea, and Kattamis, 1962; Choremis et al., 1963; Fraser et al., 1963; Allison et al., 1963; Stamatoyannopoulos and Fessas, 1964; Stamatoyannopoulos, Panayotopoulos, and Motulsky, 1966b).

The most common variant of G6PD deficiency shown so far is the severe Mediterranean type, though some isolated instances of other rare variants have also been reported (Kattamis, 1963; Stamatoyannopoulos, Panayotopoulos, and Papayannopoulou, 1964). The severe Mediterranean type is the main enzymatic variant which has been incriminated for the pathogenesis of favism (Kattamis, Kyriazakou, and Chaidas, 1969) and severe neonatal jaundice (Doxiadis et al., 1961).

In this country favism is the commonest type of acute haemolytic anaemia and it is usually found in areas with a high incidence of enzyme deficiency. Clinical observations suggest that favism, though occurring in these areas, is surprisingly rare considering the number of people at risk, and the frequency of exposure to Vicia faba ; they also indicate that favism is not always proportional to the frequency of G6PD deficiency (C. Kattamis, unpublished data).

The present investigation was undertaken to elucidate the relation of favism to G6PD deficiency as well as the variability which may exist in the susceptibility of sensitive individuals exposed to Vicia

Received December 24, 1968

* Supported in part by Grant 743 from the Royal Hellenic Research Foundation.

† In receipt of a WHO Exchange Workers Grant. faba from one area to another. Rhodes was selected, as it was known that in this island both favism and G6PD deficiency were relatively common. We studied: (a) the frequency and geographical distribution of G6PD deficiency in the island; (b) the prevalence of favism among deficient individuals; and (c) the geographical distribution of favism and its relation to that of G6PD deficiency.

\section{Material and Methods}

Rhodes is the main island of the Dodecanese at the remote North East region of the Aegean Sea. It has an area of 1404 square kilometres and a population of 56,819 ; it consists mainly of lowlands and semimountainous areas $(200-700 \mathrm{~m}$.), with only a small mountainous region above $700 \mathrm{~m}$. A mountain range divides the island into two regions, the north and the south.

Before 1946 (when the national malaria control programme was introduced) malaria used to be prevalent in Rhodes. At present the disease has been completely eradicated.

A total of 709 schoolboys, aged 10-16 years, were studied under the following 3 groups.

Group I: 451 boys from all over the island, representing $2.3 \%$ of the total male population.

Group II: 187 boys from selected areas which were chosen either for their high incidence of G6PD deficiency, group A (villages of Kremasti and Archangelos), or because they were known to local physicians for their high incidence of favism, group B (Sianna, St. Isidoros, Laerma).

Group III: 71 boys representing 3.5\% of the male population of the Turkish minority of the island.

For each person examined, the exact place of origin of the mother and her ancestors was recorded, and data concerning favism and drug sensitivity were collected. The parents of all 143 detected deficient males were retrospectively questioned about the frequency and approximate quantity of fava beans ingested by their child, and the type and degree of any untoward effect 
which this ingestion evoked. The diagnosis of favism was accepted only when severe general distress, pallor, jaundice, and gross haemoglobinuria occurred after exposure to Vicia faba.

An approximate index of the geographical distribution of favism based on the prevalence of the disease in the population of various areas of the island was obtained by analysing the data of 121 patients with favism treated at the Children's Department of the General Hospital of Rhodes in the years 1952-1965. These patients were also used to study the differences in susceptibility of deficient individuals in various areas, by comparing the morbidity rate of the disease in the expected male deficient and sensitive populations of the area; this theoretically was the population at risk.

Venous blood (5-6 ml.) was collected in ACD mixture for a series of haematological investigations. G6PD activity was determined by the brilliant cresyl blue (BCB) decolorization test (Motulsky and CampbellKraut, 1961). Samples decolorizing in 30-70 minutes were considered normal, those between 70 and 150 minutes were suspect, and above 150 minutes they were deficient. These criteria were slightly different from those used in some of our previous studies (ZannosMariolea and Kattamis, 1961; Choremis et al., 1962, 1963). All deficient and suspect samples were reexamined two or three times, and the G6PD activity was assayed by the method of Zinkham, Lenhard, and Childs (1958). In a number of cases the methaemoglobin reduction test (Brewer, Tarlov, and Alving, 1960) was also applied.

\section{Results}

G6PD Deficiency. The incidence of G6PD deficiency in the total male population was $24.6 \%$. Minor differences are shown in Table $I$, and were observed between the general sample $(22 \cdot 2 \%)$ and the selected sample $(25 \cdot 8 \%)$.

Enzymic deficiency was rare $(2 \cdot 8 \%)$ among the Turkish minority of the island.

The distribution of G6PD deficiency in the island is shown in Table II. The frequency in the south $(27.4 \%)$ differs significantly from that in the north $(16.3 \%)\left(\chi^{2}=7.99,1\right.$ d.f., $\left.\mathrm{p}<0.01\right)$. The slightly lower frequencies observed in the semi-mountainous

\section{TABLE I}

G6PD DEFICIENCY IN GENERAL AND SELECTED SAMPLES

\begin{tabular}{l|c|c|c}
\hline Sample & $\begin{array}{c}\text { No. } \\
\text { Examined }\end{array}$ & $\begin{array}{c}\% \text { of Total } \\
\text { Male } \\
\text { Population }\end{array}$ & $\begin{array}{c}\text { Prevalence } \\
\text { of G6PD } \\
\text { Deficiency } \\
(\%)\end{array}$ \\
\hline General & 451 & $2 \cdot 3$ & $22 \cdot 2$ \\
Selected & 187 & $5 \cdot 6$ & $\begin{array}{r}25 \cdot 8 \\
2 \cdot 8\end{array}$ \\
\hline Turks & 71 & $3 \cdot 5$ & $24 \cdot 6$ \\
\hline Total & 709 & $2 \cdot 5$ & 24 \\
\hline
\end{tabular}

TABLE II

G6PD DEFICIENCY IN LOWLAND AND SEMIMOUNTAINOUS AREAS OF THE NORTH AND SOUTH REGIONS OF RHODES

\begin{tabular}{|c|c|c|c|c|}
\hline Main Areas & $\begin{array}{c}\text { No. } \\
\text { Examined }\end{array}$ & $\begin{array}{l}\text { o of Male } \\
\text { Population }\end{array}$ & $\begin{array}{c}\text { No. } \\
\text { Deficient }\end{array}$ & $\begin{array}{c}\text { Prevalence } \\
\text { of G6PD } \\
\text { Deficiency } \\
(0,0)\end{array}$ \\
\hline $\begin{array}{l}\text { North region } \\
\text { Lowland } \\
\text { Semi- } \\
\text { mountainous }\end{array}$ & $\begin{array}{r}181 \\
31\end{array}$ & $\begin{array}{l}1 \cdot 0 \\
1 \cdot 9\end{array}$ & $\begin{array}{r}31 \\
4\end{array}$ & $\begin{array}{l}16 \cdot 9 \\
12 \cdot 9\end{array}$ \\
\hline Total & 214 & $1 \cdot 1$ & 35 & $16 \cdot 3$ \\
\hline $\begin{array}{l}\text { South region } \\
\text { Lowland } \\
\text { Semi- } \\
\text { mountainous }\end{array}$ & $\begin{array}{r}197 \\
40\end{array}$ & $\begin{array}{l}4 \cdot 4 \\
2 \cdot 0\end{array}$ & $\begin{array}{r}56 \\
9\end{array}$ & $\begin{array}{l}28 \cdot 4 \\
22 \cdot 5\end{array}$ \\
\hline Total & 237 & $3 \cdot 1$ & 65 & $27 \cdot 4$ \\
\hline
\end{tabular}

TABLE III

G6PD DEFICIENCY IN SELECTED AREAS

\begin{tabular}{|c|c|c|c|c|}
\hline Villages & $\begin{array}{l}\text { No. } \\
\text { Examined }\end{array}$ & $\begin{array}{l}0 \text { of Male } \\
\text { Population }\end{array}$ & $\begin{array}{c}\text { No. } \\
\text { Deficient }\end{array}$ & $\begin{array}{c}\text { Prevalence } \\
\text { of G6PD } \\
\text { Deficiency } \\
(\%)\end{array}$ \\
\hline $\begin{array}{l}\text { Group } A \\
\text { Kremasti } \\
\text { Archangelos } \\
\text { Group } B\end{array}$ & $\begin{array}{r}49 \\
132\end{array}$ & $\begin{array}{r}5.0 \\
10 \cdot 0\end{array}$ & $\begin{array}{l}17 \\
28\end{array}$ & $\begin{array}{l}34 \cdot 7 \\
21 \cdot 2\end{array}$ \\
\hline $\begin{array}{l}\text { Sianna } \\
\text { St. Isidoros } \\
\text { Laerma }\end{array}$ & $\begin{array}{l}24 \\
53 \\
40\end{array}$ & $\begin{array}{l}13 \cdot 6 \\
10 \cdot 7 \\
12 \cdot 6\end{array}$ & $\begin{array}{r}8 \\
10 \\
14\end{array}$ & $\begin{array}{l}33 \cdot 3 \\
18 \cdot 8 \\
35 \cdot 0\end{array}$ \\
\hline
\end{tabular}

areas compared to the lowland regions, in either the north $(12.9 \%: 16.9 \%)$ or the south $(22.5 \%: 28.4 \%)$ were not statistically significant $(p<0 \cdot 5)$.

There were certain foci with high frequencies of enzymic deficiency. Two of them, Kremasti and Archangelos (group A), were further investigated, together with the villages of Sianna, St. Isidoros, and Laerma (group B) which were already known as foci of favism.

The results of this work on selected groups are shown in Table III. High frequencies were found in Kremasti (34.7\%), Sianna (33.3\%), and Laerma (35.0\%).

Analysis of the combined data obtained from the general and the selected groups allowed us to plot the geographical distribution of G6PD deficiency shown in Fig. 1. This illustrates the uneven distribution of G6PD deficiency in the island; lower frequencies were noted in the upper north region $(8-15 \%)$ and higher frequencies in the lowland areas of the south and south east regions $(>30 \%)$, while in the north east region and the semi-mountainous areas the frequency ranged from $15-20 \%$, 


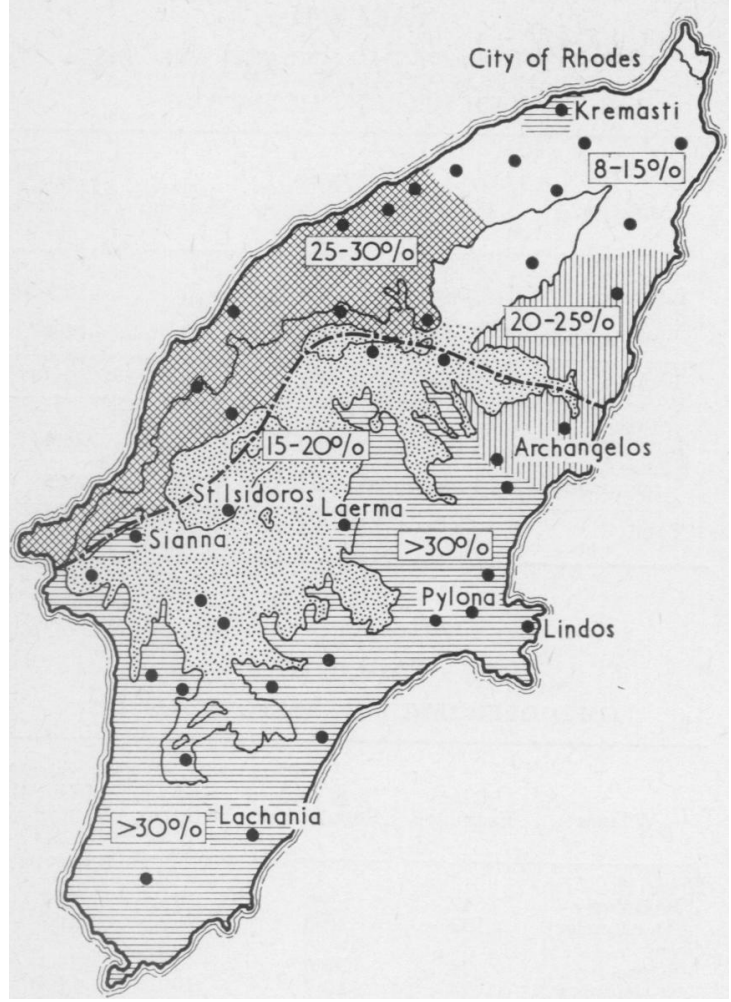

FIG. 1. Geographical distribution of G6PD deficiency in Rhodes.

and in the north west from $20-25 \%$. It is interesting that the frequency of enzymic deficiency increases gradually from north to south, and that the isolated foci with high frequencies, like Kremasti $(34.7 \%)$ and Sianna $(33.3 \%)$, were detected in areas with much lower frequencies.

\section{Susceptibility of G6PD Deficient Subjects to}

Vicia faba. This is shown in Table IV. Of 143 deficient boys exposed to fava beans, only $18(13 \%)$ had clinical signs compatible with the diagnosis of favism. Only $3(7 \%)$ cases of favism were found among 43 sensitive subjects who originated from the north compared to $15(15 \%)$ among 100 deficient subjects from the south.

The variability in susceptibility was more pronounced in selected areas. None of the 45 deficient boys originating from the areas of group A had favism; on the contrary, 9 cases $(28 \%)$ were disclosed among 32 sensitive subjects from group B. The difference in susceptibility to Vicia faba among the sensitive people of these areas was statistically significant $\left(\chi^{2}=82.3\right.$, d.f. $\left.1, \mathrm{p}<0.001\right)$.

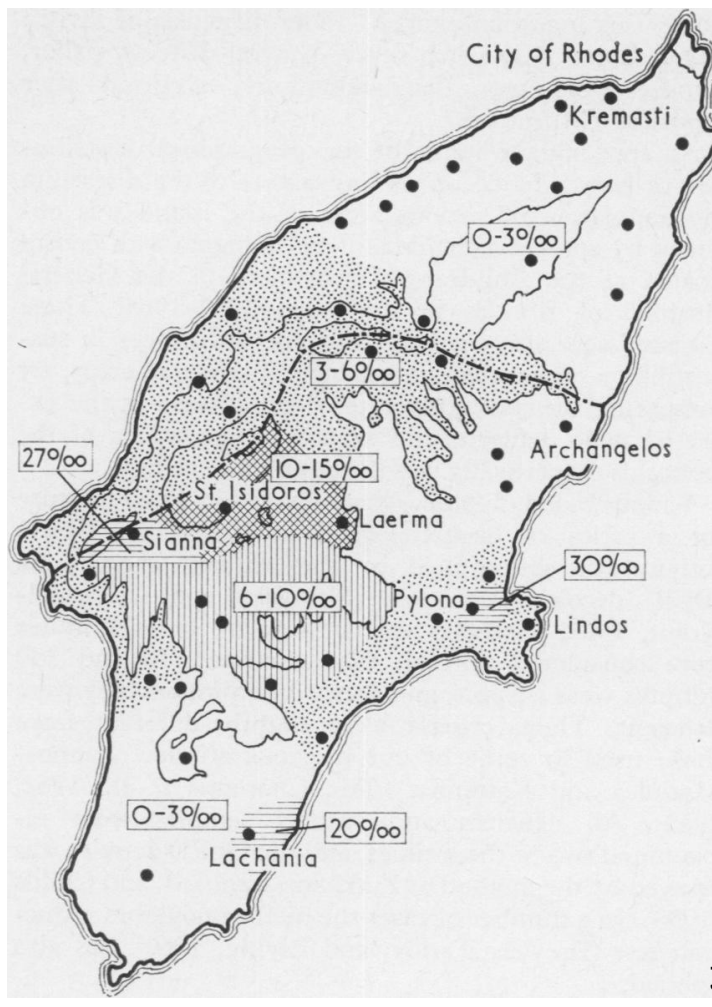

FIG. 2. Geographical distribution of favism in Rhodes.

TABLE IV

PREVALENCE OF FAVISM AMONG G6PD DEFICIENT INDIVIDUALS IN RHODES

\begin{tabular}{|c|c|c|c|}
\hline Area & $\begin{array}{c}\text { No. } \\
\text { Deficient }\end{array}$ & $\begin{array}{l}\text { Instances } \\
\text { of Favism }\end{array}$ & $\begin{array}{c}\text { Prevalence } \\
\text { of Favism } \\
\text { in } \\
\text { Deficient } \\
\begin{array}{c}\text { Subjects } \\
(\%)\end{array}\end{array}$ \\
\hline $\begin{array}{l}\text { North } \\
\text { South }\end{array}$ & $\begin{array}{r}43 \\
100\end{array}$ & $\begin{array}{r}3 \\
15\end{array}$ & $\begin{array}{r}6.9 \\
15.0\end{array}$ \\
\hline Rhodes (total) & 143 & 18 & $12 \cdot 6$ \\
\hline $\begin{array}{l}\text { Selected } \\
\text { Kremasti } \\
\text { Archangelos } \\
\end{array}$ & $\begin{array}{l}17 \\
28 \\
\end{array}$ & $\begin{array}{l}\mathbf{0} \\
0 \\
\end{array}$ & $\begin{array}{l}0 \\
0 \\
\end{array}$ \\
\hline Group A (total) & 45 & 0 & 0 \\
\hline $\begin{array}{l}\text { Sianna } \\
\text { St. Isidoros } \\
\text { Laerma }\end{array}$ & $\begin{array}{r}8 \\
10 \\
14\end{array}$ & $\begin{array}{l}3 \\
5 \\
1\end{array}$ & $\begin{array}{l}37 \cdot 5 \\
50 \cdot 0 \\
14 \cdot 5\end{array}$ \\
\hline Group B (total) & 32 & 9 & $28 \cdot 1$ \\
\hline
\end{tabular}

Geographical Distribution of Favism. The variability of the prevalence of favism in the island is shown in Fig. 2, and is based on the place of origin 
TABLE V

MORBIDITY RATES OF FAVISM BETWEEN 1952-1965 AMONG DEFICIENT MALES IN RHODES

\begin{tabular}{|c|c|c|c|c|c|}
\hline Area & $\begin{array}{c}\text { Male } \\
\text { Popula- } \\
\text { tion }\end{array}$ & $\begin{array}{c}\text { Prevalence } \\
\text { of G6PD } \\
\text { Deficiency } \\
\left({ }_{0}^{\circ}\right)\end{array}$ & $\begin{array}{c}\text { Expected } \\
\text { G6PD- } \\
\text { deficient } \\
\text { Males }\end{array}$ & $\begin{array}{c}\text { Cases } \\
\text { of } \\
\text { Favism }\end{array}$ & $\begin{array}{l}\text { Mor- } \\
\text { bidity } \\
\text { Rate } \\
(\%)\end{array}$ \\
\hline \multirow{2}{*}{$\begin{array}{l}\text { North } \\
\text { Rhodes (city) } \\
\text { South } \\
\text { Selected } \\
\quad \text { Kremasti } \\
\text { Archangelos }\end{array}$} & $\begin{array}{r}10,271 \\
10,116 \\
6460\end{array}$ & $\begin{array}{r}16 \cdot 4 \\
8 \cdot 0 \\
27 \cdot 4\end{array}$ & $\begin{array}{r}1684 \\
809 \\
1770\end{array}$ & $\begin{array}{l}36 \\
10 \\
75\end{array}$ & $\begin{array}{l}2 \cdot 2 \\
1 \cdot 2 \\
4 \cdot 3\end{array}$ \\
\hline & $\begin{array}{r}986 \\
1359\end{array}$ & $\begin{array}{l}34 \cdot 7 \\
21 \cdot 2\end{array}$ & $\begin{array}{l}331 \\
287\end{array}$ & $\begin{array}{l}2 \\
4\end{array}$ & $\begin{array}{l}0.6 \\
1.4\end{array}$ \\
\hline Group A (total) & 2345 & $26 \cdot 3$ & 618 & 6 & 0.9 \\
\hline $\begin{array}{l}\text { Sianna } \\
\text { St. Isidoros } \\
\text { Laerma } \\
\text { Pylona }\end{array}$ & $\begin{array}{l}176 \\
496 \\
318 \\
101\end{array}$ & $\begin{array}{l}35 \cdot 0 \\
18 \cdot 8 \\
33 \cdot 3 \\
25 \cdot 0\end{array}$ & $\begin{array}{r}61 \\
92 \\
105 \\
25\end{array}$ & $\begin{array}{r}8 \\
15 \\
10 \\
7\end{array}$ & $\begin{array}{l}13 \cdot 2 \\
16 \cdot 4 \\
10 \cdot 0 \\
28 \cdot 0\end{array}$ \\
\hline Group B (total) & 1091 & $26 \cdot 0$ & 283 & 40 & $15 \cdot 0$ \\
\hline
\end{tabular}

of 121 patients treated in the General Hospital of the island. The disease was also unevenly distributed. Contrary to what would be expected if G6PD deficiency were the only factor responsible for susceptibility to fava beans, the prevalence of favism was not always proportional to the incidence of G6PD deficiency, and the geographical distribution of favism varied in many instances from that of G6PD deficiency (Fig. 1 and 2). The prevalence of favism among the whole population during the years 1952-1965 was found to be 1.7 per thousand for the north, 0.46 for the city of Rhodes, and 5.36 for the southern region.

More impressive were the figures for selected areas. In Kremasti and Archangelos (group A) favism was rarely seen, and the prevalence of the disease was 0.97 and 1.36 per thousand, respectively, while in Laerma, St. Isidoros, Sianna, and Pylona favism was seen frequently, with rates of $11.9,14$, 27.2 , and 30.9 per thousand. A more accurate index of the variability of susceptibility to favism was obtained by the approximate morbidity rate of favism among the expected male sensitive populations of the investigated areas. Results are shown in Table $\mathrm{V}$.

The morbidity for the years $1952-1965$ was $2.2 \%$ in the north, $1.2 \%$ in the city of Rhodes itself, and $4.3 \%$ in the south. In selected areas and in group A, the morbidity among 618 deficient males was only $0.9 \%$ compared to the $15.0 \%$ among $283 \mathrm{de}-$ ficient boys from group $B$. The difference is statistically highly significant.

\section{Discussion}

The frequency of G6PD deficiency found in the island of Rhodes $(22.4 \%)$ is very high. Figures re- ported by Allison et al. (1963) for Rhodes (31.8\%) and Chalkidiki $(32.4 \%$ ), though slightly higher, were not representative for these areas, as the investigation was restricted to certain selected villages. In the case of Rhodes selected villages are situated in the South region of the island, where according to our data the deficiency rate is above $30 \%$ (Fig. 1).

Extensive population studies in Greece revealed a high incidence of G6PD deficiency in some other areas, namely Orchomenos (14.5\%), the lowland areas of Arta (16.4\%), and Karditsa (19.8\%). In the past malaria had been endemic, and in addition to G6PD deficiency, the sickle-cell trait frequencies ranged from $2 \cdot 5-20 \cdot 2 \%$ (Choremis et al., 1962, 1963; Stamatoyannopoulos and Fessas, 1964). In Rhodes the sickle-cell trait was completely absent; it has not been detected in any of the 451 schoolboys examined.

On the other hand, $\beta$-thalassaemia trait was high, and we found an incidence of $16 \%$ (unpublished data), while Barnicot et al. (1963) reported a somewhat higher frequency of $20.2 \%$. These figures indicate that the incidences of G6PD deficiency and $\beta$-thalassemia trait in Rhodes are the highest reported so far for Greece.

It is difficult to determine the selective forces which were operating for centuries in preserving these abnormal genes in high frequencies as well as in causing the uneven distribution of G6PD deficiency in a small island like Rhodes.

Malaria used to have a moderate degree of endemicity. Unfortunately, accurate data are not available, but there is a widespread opinion among the practising physicians that the disease was hyperendemic in the south. At any rate, differences in the malaria endemicity, if there were any, are expected to be small and cannot explain the uneven distribution of G6PD deficiency and especially the highly significant differences that were noted between the north and the south regions. Inbreeding, which was common in villages, may explain the high incidences of both G6PD deficiency and favism seen in isolated communities. The main selective factors, however, are still not known.

The exceptionally low frequency of G6PD deficiency among Turks $(2.8 \%)$ can be correlated with figures reported by Fraser et al. (1964) in Turkish minorities in Thrace. Environmental factors had few chances of selective action, as the Turks are a close community which immigrated to the island during the past 3-4 centuries.

Selection is known to operate against the G6PD deficiency gene because affected hemizygotes are liable to haemolysis after ingestion of fava beans and 
on exposure to certain drugs and infections later in life (Motulsky, 1965).

In Rhodes, cultivation and consumption of Vicia $f a b a$ is extensive, though there is a local ordinance which had never been enforced, forbidding cultivation. With such high rates of enzymic deficiency among the male population of the island and the extensive consumption of beans, favism was expected to be extremely frequent. At least among the 143 deficient hemizygotes detected in this series, only $18(12.8 \%)$ experienced haemolysis after eating fava beans. This indicates the relative infrequency of favism among the individuals at risk.

As has been previously shown, the disease is more frequently found among children aged 2-5 years. After the age of 10 the disease declines sharply and is found in adults only exceptionally (Kattamis et al., 1969). As all hemizygotes studied were above 10 years of age the chances of experiencing a haemolytic crisis later in life were limited. It has also been shown that variability in the susceptibility of sensitive individuals exists from one region to another. Most impressive were the differences in susceptibility, between 42 hemizygotes from group A, none of whom had favism, and 35 hemizygotes with $9(28.4 \%)$ instances of favism from group $B$ in which the disease was known to prevail.

These findings indicate that the prevalence of favism in an area is not related only to G6PD deficiency rates but also to the degree of susceptibility of deficient individuals to Vicia faba.

Though the data of this study do not represent the exact morbidity rate, which is expected to be higher (as a number of patients, especially from the south, may have failed to enter the hospital because of difficulties in transportation), they are sufficient to show the differences in the prevalence of the disease and the susceptibility of sensitive individuals in certain areas of the island. In addition, they confirm that G6PD deficiency does not necessarily lead to favism after exposure to Vicia faba, and that some other unknown factors enhance the susceptibility of sensitive individuals to haemolysis.

The relative infrequency and the variability of susceptibility to favism of individuals at risk may be attributed to a variety of causes, such as differences in Vicia faba consumption, limited occurrence of the noxious agent among different sources of beans, and qualitative differences in the noxious agent.

In the case of the island of Rhodes, these explanations probably do not apply, because the kind of bean which is cultivated is the same all over the island and the frequency of consumption is more or

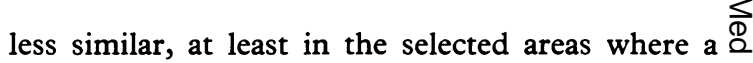
careful interrogation was made.

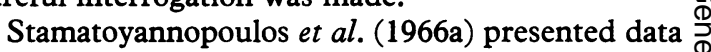
indicating the existence of a familial predisposition to favism, which could be attributed to an abnormal $\underset{\vec{F}}{\vec{F}}$ autosomal gene which, in the heterozygous state, enhances the susceptibility of deficient individuals $\frac{\bar{\sigma}}{\sigma}$ to haemolysis.

This hypothesis could explain the great differences in susceptibility of sensitive individuals observed in the two groups of selected areas. In group A, where in spite of the high incidence of $\vec{O}$ deficiency favism was extremely rare, the additional $\vec{\overrightarrow{ }}$ genetic factor enhancing susceptibility could be $\stackrel{\omega}{\sigma}$ absent, while in group B, where favism was common and the susceptibility considerable, it would exist at a high frequency.

The possibility of the existence of additional genetic factors in these areas is enforced by the fact of that the villages are isolated and that there is considerable inbreeding.

The nature of the hypothetical second hereditary factor could involve the red cell itself, or the absorption, detoxication, or excretion of the noxious agent of Vicia faba.

Enzyme electrophoretic studies in patients with favism and G6PD deficient individuals without haemolytic crisis, showed the same pattern (Ge Kattamis, unpublished data). On the other hand the enzymic variant which prevails in Rhodes 18 that of the common Mediterranean type. Of 100 deficient in the general sample studied by quantitative G6PD activity determination, only 5 had an activity level corresponding to that of the mild Mediterranean variant. The enzymic activity in these instances ranged from $17-60 \%$ of the normal mean. Family studies of the same patients disclosed 9 more males with deficiency and with the same activity levels of $15-65 \%$ of the normal mean (Matsaniotis et al., 1966). None of them had signs of haemolysis after ingestion of beans.

Undoubtedly, population studies and detection of areas with a high susceptibility of deficient hemizygotes to favism could help considerably in clarifying the pathogenesis of the disease.

\section{Summary}

The Mediterranean variant of G6PD deficiency has been known to be associated with the pathogenesis of favism, though the exact relation between the two has not been clearly defined. An extensive study in the island of Rhodes where both G6PD deficiency and favism exist, disclosed a high incidence $(22 \%)$ of enzymic deficiency in the general 
population (the highest reported so far for areas of Greece) and considerable variability in its geographical distribution.

In different areas of Rhodes the prevalence of favism was not always proportional to that of G6PD deficiency. Investigation of the morbidity rate and the incidence of favism among detected hemizygotes in various areas of the island showed considerable differences in the susceptibility of sensitive individuals to Vicia faba. These findings confirm the assumption that some other unknown factor or factors besides G6PD deficiency are increasing the susceptibility of sensitive individuals to haemolysis after ingestion of fava beans.

The authors wish to express their appreciation and thanks to Professor H. Lehmann for helpful criticisms, to Drs. George Perdikakis and Christos Hiraklidis of Rhodes for permission to quote their data on favism, and to Dr. Maria Kyriazakou for valuable help.

\section{REFERENCES}

Allison, A. C., Askonas, A. B., Barnicot, N. A., Blumberg, B. S., and Krimbas, C. (1963). Deficiency of erythrocyte glucose-6-phosphate dehydrogenase in Greek populations. Ann. hum. Genet., 26, 237.

Barnicot, N. A., Allison, A. C., Blumberg, B. S., Deliyannis, G., Krimbas, C., and Ballas, A. (1963). Haemoglobin types in Greek populations. ibid., 26, 229.

Brewer, G., Tarlov, A., and Alving, A. (1960). Methemoglobin reduction test. Bull. Wld Hlth Org., 22, 633.

Choremis, C., Fessas, Ph., Kattamis, C., Zannos-Mariolea, L., Stamatoyannopoulos, G., Zannos-Mariolea, L., Karaklis, A., and Belios, G. (1963). Three inherited red-cell abnormalities in a district of Greece. Thalassaemia, sickling and glucose-6-phosphate-dehydrogenase deficiency. Lancet, $1,907$.

-, Zannos-Mariolea, L., and Kattamis, M. D. C. (1962). Frequency of glucose-6-phosphate-dehydrogenase deficiency in certain highly malarious areas of Greece. ibid., 1, 17.
Doxiadis, S. A., Fessas, Ph., Valaes, T., and Mastrokolos, N. (1961). Glucose-6-phosphate-dehydrogenase deficiency. A new aetiological factor of severe neonatal jaundice. ibid., 1, 297.

Fraser, G. R., Defaranas, B., Kattamis, C. A., Race, R. R., Sanger, R., and Stamatoyannopoulos, G. (1964). Glucose-6-phosphate dehydrogenase deficiency, colour vision and $\mathrm{Xg}$ blood groups in Greece. Linkage and population data. Ann. hum. Genet., 27, 395.

- Stamatoyannopoulos, G., Kattamis, C., Loukopoulos, D. Defaranas, B., Kitsos, C., Zannos-Mariolea, L., Choremis, C., Fessas, P., and Motulsky, A. G. (1963). Thalassemias abnormal hemoglobins and glucose-6-phosphate dehydrogenase deficiency in Arta area of Greece. Diagnostic and genetic aspects of complete village studies. Ann. N.Y. Acad. Sci., 119, 415.

Kattamis, C. A. (1963). Red cell acid phosphomonoesterase activity in normal and glucose-6-phosphate dehydrogenase deficient erythrocytes. Thesis, University of Athens.

- Kyriazakou, M., and Chaidas, S. (1969). Favism. Clinical and biochemical data. F. med. Genet., 6, 134.

Matsaniotis, N., Kattamis, C. A., Kyriazakou, M., Metaxotou, A., Chaidas, St., and Chaidas, A. (1966). Genetic studies on the mild type of glucose-6-phosphate dehydrogenase deficiency. Delt. paediat. Klin. Panep. Athin., 13, 402.

Motulsky, A. G. (1965). Theoretical and clinical problems of glucose-6-phosphate dehydrogenase deficiency. Its occurrence in Africans and its combination with haemoglobinopathy. In Abnormal Haemoglobins in Africa, pp. 143-196. Ed. by J. H. P. Jonxis. Blackwell Scientific Publications, Oxford.

, and Campbell-Kraut, J. M. (1961). Population genetics of glucose-6-phosphate dehydrogenase deficiency of the red cell. In Proceedings of the Conference on Genetic Polymorphisms and Geographic Variation in Disease, pp. 159-180. Ed. by B. S. Blumberg. Grune and Stratton, New York.

Stamatoyannopoulos, G., and Fessas, Ph. (1964). Thalassaemia, glucose-6-phosphate dehydrogenase deficiency, sickling and malarial endemicity in Greece. A study of five areas. Brit. med. F., $1,875$.

1, Fraser, G. R., Motulsky, A. G., Fessas, Ph., Akrivakis, A., and Papayannopoulou, Th. (1966a). On the familial predisposition to favism. Amer. F. hum. Genet., 18, 253.

- Panayotopoulos, A., and Motulsky, A. G. (1966b). The distribution of glucose-6-phosphate dehydrogenase deficiency in Greece. ibid., 18, 296.

,-- , and Papayannopoulou, Th. (1964). Mild glucose-6phosphate dehydrogenase deficiency in Greek males. Lancet, 2, 932.

Zannos-Mariolea, L., and Kattamis, C. (1961). Glucose-6-phosphate dehydrogenase deficiency in Greece. Blood, 18, 34 .

Zinkham, W. H., Lenhard, R. E., and Childs, B. (1958). A deficiency of glucose-6-phosphate dehydrogenase activity in erythrocytes from patients with favism. Bull. Johns Hopk. Hosp., 102, 169. 